\title{
Sensitivity of grapevine powdery mildew (Erysiphe necator) to demethylation inhibitor and quinone outside inhibitor fungicides in New Zealand
}

\author{
R.M. Beresford ${ }^{1}$, P.J. Wright ${ }^{2}$, P.N. Wood ${ }^{3}$ and R.H. Agnew ${ }^{4}$ \\ ${ }^{1}$ The New Zealand Institute for Plant \& Food Research Ltd, Mt Albert Research Centre, \\ Private Bag 92169, Auckland 1142, New Zealand \\ ${ }^{2}$ The New Zealand Institute for Plant \& Food Research Limited, Pukekohe Research Centre, \\ Cronin Road, RD1 Pukekohe, New Zealand \\ ${ }^{3}$ The New Zealand Institute for Plant \& Food Research Ltd, Hawke's Bay Research Centre, \\ Private Bag 1401, Havelock North, Hastings 4157, New Zealand \\ ${ }^{4}$ The New Zealand Institute for Plant \& Food Research Ltd, Marlborough Wine Research Centre, \\ PO Box 845, Blenheim 7240, New Zealand \\ Corresponding author: robert.beresford@plantandfood.co.nz
}

\begin{abstract}
Isolates of Erysiphe necator from Hawke's Bay and Marlborough vineyards were tested for sensitivity to three demethylation inhibitor (DMI) fungicides (myclobutanil, penconazole and cyproconazole) and one quinone outside inhibitor (QoI) fungicide (trifloxystrobin). Mean colony diameter was determined in a detached grape leaf assay for approximately 20 isolates per vineyard at 1 and $10 \mathrm{mg} /$ litre of each fungicide. Resistance to trifloxystrobin was prevalent in Hawke's Bay and Marlborough. Mycobutanil resistance was found in both regions, but particularly in Marlborough. There was some loss of sensitivity to penconazole, particularly in Marlborough. Cyproconazole showed greater efficacy against E. necator than the other two DMIs tested. There was no explanation for the high trifloxystrobin resistance in sampled vineyards with few reports of trifloxystrobin use. For DMIs, there was a strong relationship between number of DMI fungicide applications over 10 years and DMI resistance across all three DMI active ingredients in both regions.
\end{abstract}

Keywords Erysiphe necator, Uncinula necator, Grapevine powdery mildew, resistance management, fungicide resistance, demethylation inhibitor, fungicides, myclobutanil, penconazole and cyproconazol, quinone outside inhibitor, trifloxystrobin

\section{INTRODUCTION}

Grapevine powdery mildew (Erysiphe necator; previously Uncinula necator) is known to develop resistance to some modern fungicides with site-specific modes of action. Resistance to demethylation inhibitor (DMI) fungicides, which have been in use in New Zealand and elsewhere for about 30 years, has been reported in several countries, including the USA (Gubler et al. 1996), Europe (Delye et al. 1997), South Africa (Halleen et al. 2000) and Australia (Savocchia et 
al. 2004). A study of E. necator DMI sensitivity in New Zealand in 1992 found that 20 isolates from Auckland, Hawke’s Bay, Gisborne, Martinborough, Marlborough, Nelson, Canterbury and Otago had high sensitivity to triadimenol, being completely inhibited by $0.3 \mathrm{mg} /$ litre (Shabi \& Gaunt 1992). Resistance to quinone outside inhibitor (QoI or strobilurin) fungicides, which have been in use in New Zealand and overseas for about 15 years, has also been reported overseas (Miles et al. 2012). For QoIs, high-level resistance in E. necator can develop as a result the G143A mutation in the cytochrome b gene (Baudoin et al. 2008).

There have been anecdotal reports of increased powdery mildew severity in recent seasons in New Zealand's main grape-growing areas, including Marlborough, Hawke's Bay and Gisborne. While poor powdery mildew control could result from seasonal weather conditions that are particularly favourable for powdery mildew (e.g. warm dry summers) or from poor spraying practices, the question of whether resistance is developing to key fungicides used in vineyard spray programmes needed to be addressed. This study, which was undertaken from March to April 2015 in 20 Hawke's Bay and Marlborough vineyards, sampled E. necator populations and tested them for possible resistance to DMI or QoI fungicides.

\section{MATERIALS AND METHODS Collection of Erysiphe necator isolates}

Grapevine leaves with powdery mildew lesions were collected into individual polythene bags from 10 vineyards in Hawke's Bay and 10 in Marlborough during March and April 2015 (Table 1). Samples were sent to Plant \& Food Research at Pukekohe, where single lesion isolates of E. necator were obtained by rubbing lesion pieces onto young (second unrolled leaf from the shoot tip) surface-sterilised Sauvignon blanc leaves from a nearby vineyard. Leaves were surface-sterilised by immersing in calcium hypochlorite (50 g/litre) for $3 \mathrm{~min}$, followed by triple rinsing in sterile distilled water. These leaves were placed adaxial side up on $1 \%$ water agar in 90 -mm Petri dishes with the leaf petiole trimmed and inserted into the agar. The inoculated leaves were incubated on a laboratory bench under fluorescent lights (ca 1000 lux) with a $14 \mathrm{~h}$ photoperiod at about $22^{\circ} \mathrm{C}$. Sporulating powdery mildew colonies developed after about 21 days and single conidial chains were transferred to new surface-sterilised leaves. Isolates could thus be maintained by repeated transfer every 4-5 weeks, until no more young grape leaves were available from the vineyard.

\section{Fungicide sensitivity assay}

Young Sauvignon blanc leaves were collected and surface sterilised, as described above. After drying, each leaf was soaked in one of the test fungicide suspensions for $1 \mathrm{~h}$, allowed to dry and then placed on water agar, as described above. Conidia of each E. necator isolate were inoculated into a marked circle ( 2 to $2.5 \mathrm{~cm}$ dia.) in the centre of the test leaf using a sterile acupuncture needle. After 21 days incubation (as described above) the diameter of the colony area that sporulated was measured under a binocular microscope (32x magnification). For each isolate there were duplicate control (no fungicide) inoculations and one inoculation for each fungicide concentration.

Three DMI fungicides (myclobutanil, penconazole and cyproconazol) and one QoI fungicide (trifloxystrobin) were tested, each at $1 \mathrm{mg} /$ litre and $10 \mathrm{mg} /$ litre (Table 2). The lower discriminatory dose of $1 \mathrm{mg} /$ litre was chosen from published information about $\mathrm{EC}_{50}$ values (fungicide concentration that inhibits colony diameter by $50 \%$ ) associated with resistant isolates in the USA, for both DMIs (Gubler et al. 1996) and QoIs (Baudoin et al. 2008). This concentration was just above the $\mathrm{EC}_{50}$ of highly sensitive isolates and growth at this dose allowed isolates with low-level resistance to be identified. The upper dose of $10 \mathrm{mg} /$ litre was used to detect high-level resistant isolates. 
Table 1 Number of Erysiphe necator isolates per vineyard that were collected from 10 Hawke's Bay and 10 Marlborough vineyards (total of 346 isolates) in March and April 2015 for fungicide sensitivity testing. Vineyards in bold were under organic management.

\begin{tabular}{|c|c|c|c|c|c|}
\hline \multicolumn{3}{|l|}{ Marlborough } & \multicolumn{3}{|l|}{ Hawke's Bay } \\
\hline Vineyard no. & Variety & No. Isolates & Vineyard no. & Variety & No. Isolates \\
\hline 1 & ${ }^{5} \mathrm{Sb}$ & 20 & ${ }^{3} 8$ & $\mathrm{Sb}$ & 16 \\
\hline${ }^{1} 2$ & Sb & 20 & ${ }^{4} 9$ & ${ }^{6}$ Ver & 15 \\
\hline 3 & $\mathrm{Sb}$ & 20 & 10 & $\mathrm{Sb}$ & 20 \\
\hline 4 & $\mathrm{Sb}$ & 18 & 11 & $\mathrm{Sb}$ & 12 \\
\hline 5 & $\mathrm{Sb}$ & 18 & 15 & $\mathrm{Sb}$ & 12 \\
\hline 6 & $\mathrm{Sb}$ & 19 & 16 & ${ }^{7} \mathrm{Ch}$ & 18 \\
\hline 7 & $\mathrm{Sb}$ & 18 & 17 & $\mathrm{Sb}$ & 19 \\
\hline 12 & $\mathrm{Sb}$ & 17 & 18 & $\mathrm{Sb}$ & 20 \\
\hline${ }^{2} 13$ & Sb & 19 & 19 & $\mathrm{Sb}$ & 20 \\
\hline \multirow[t]{2}{*}{14} & $\mathrm{Sb}$ & 18 & 20 & $\mathrm{Sb}$ & 7 \\
\hline & Total & 187 & & Total & 159 \\
\hline
\end{tabular}

${ }^{1}$ Organic management since 2009; ${ }^{13}$ Organic management since 2009

${ }^{3}$ Organic management since 2005; ${ }^{4} 9$ Organic management since 2008

${ }^{5}$ Sauvignon blanc; ${ }^{6}$ Verdello; ${ }^{7}$ Chardonnay

\section{Analysis of fungicide sensitivity and identification of resistance}

This research intended to determine the relative growth (colony diameter in the presence of a fungicide as a percentage of colony diameter for the no-fungicide control) for each isolate at the high and low doses and to estimate the $\mathrm{EC}_{50}$ per isolate. However, this was not possible because a large proportion of leaf inoculations failed to become infected (33\% in the controls). Instead, analyses were done at the vineyard level using analysis of variance of colony diameter in the presence of fungicide, using the individual isolates from each vineyard as replicates. Greater colony diameter indicated lower sensitivity (greater resistance). Regional sensitivity differences were examined for each fungicide using column graphs of mean colony diameter for each fungicide and concentration.

The implications of the colony diameter trends for practical resistance (Brent 1995) and for disease control were inferred by calculating relative growth at the region level and estimating regional $\mathrm{EC}_{50}$ values by regression of regional relative growth values on $\log _{10}$ of the high and low discriminatory doses. These were then examined in relation to published information about $\mathrm{EC}_{50}$

Table 2 Three demethylation inhibitors (DMI) and one quinone outside inhibitor (QoI) fungicide used for fungicide sensitivity testing of Erysiphe necator.

\begin{tabular}{cllccc}
\hline $\begin{array}{c}\text { Fungicide } \\
\text { group }\end{array}$ & $\begin{array}{c}\text { Active ingredient } \\
(\mathrm{AI})\end{array}$ & \multicolumn{1}{c}{ Product } & $\begin{array}{c}\text { A proportion in } \\
\text { product }\end{array}$ & $\begin{array}{c}\text { Lower dose } \\
(\mathrm{mg} / \text { litre AI) }\end{array}$ & $\begin{array}{c}\text { Upper dose } \\
(\mathrm{mg} / \text { litre AI) }\end{array}$ \\
\hline DMI & Myclobutanil & Systhane $^{\varpi} 200 \mathrm{E}$ & 0.20 & 1 & 10 \\
DMI & Penconazole & Citara $^{\circledR} 200 \mathrm{EW}$ & 0.20 & 1 & 10 \\
DMI & Cyproconazole & Alto $^{\varpi} 100 \mathrm{SL}$ & 0.10 & 1 & 10 \\
QoI & Trifloxystrobin & Protiva $^{\circledR}$ & 0.50 & 1 & 10 \\
\hline
\end{tabular}


Table 3 Regional means for colony diameter ( $\mathrm{mm}$ ) of Erysiphe necator in the presence of myclobutanil (myclo), penconazole (penco), cyproconazole (cypro) and trifloxystrobin (triflo), each at two concentrations. $\mathrm{P}$ values are the F-test probability from one way ANOVA on diameters for each region. Mean diameters for the no-fungicide control inoculations were $6.97 \mathrm{~mm}$ for Hawke's Bay and 6.21 for Marlborough, which were not significantly different $(\mathrm{P}=0.360)$.

\begin{tabular}{lccl}
\hline Fungicide & Hawke's Bay & Marlborough & P value \\
\hline Myclo $1 \mathrm{mg} /$ litre & 5.02 & 6.06 & 0.223 \\
Myclo $10 \mathrm{mg} /$ litre & 0.38 & 1.21 & 0.003 \\
\hline Penco $1 \mathrm{mg} /$ litre & 1.12 & 3.18 & $<0.001$ \\
Penco $10 \mathrm{mg} /$ litre & 0.00 & 0.04 & 0.357 \\
\hline Cypro $1 \mathrm{mg} /$ litre & 0.39 & 1.78 & $<0.001$ \\
Cypro $10 \mathrm{mg} /$ litre & 0.00 & 0.00 & - \\
\hline Triflo $1 \mathrm{mg} /$ litre & 4.12 & 6.25 & $<0.001$ \\
Triflo $10 \mathrm{mg} /$ litre & 4.11 & 4.64 & 0.553 \\
\hline
\end{tabular}

values associated with disease control problems.

\section{Vineyard spray programmes}

Information about the history of use of DMI and QoI fungicides in the sampled vineyard blocks was obtained using a questionnaire that was sent to each vineyard contact person. Data were requested for each growing season for the five most recent years (2010/2011 to 2014/2015), and as estimates of the average number of applications per year for earlier five year periods (2005/2006 to $2009 / 2010$ and $2000 / 2001$ to $2004 / 2005$ ) and for all years prior to 2000 . The amount of time each of the four organic vineyards had been under organic management is indicated in Table 1.

\section{RESULTS \\ Myclobutanil}

Most isolates from both regions showed substantial colony growth (indicating low sensitivity) on $1 \mathrm{mg} /$ litre myclobutanil and some growth on $10 \mathrm{mg} /$ litre (Figure 1). Mean colony diameters on $1 \mathrm{mg} /$ litre were not strongly related to those on 10 $\mathrm{mg} /$ litre for individual vineyards, except for the three least sensitive Marlborough vineyards, M1, ${ }^{\star} \mathrm{M} 2$ and M3, which showed the same trend for both concentrations. There were significant differences in sensitivity between vineyards, although no indication that the isolates from organic vineyards had smaller colony diameters (greater sensitivity) than the others. The regional colony diameter means were greater in Marlborough than in Hawke's Bay and this difference was significant $(P=0.003)$ for $10 \mathrm{mg} /$ litre (Table 3). Isolates from vineyard 20 in Hawke's Bay were more sensitive and showed no colony growth on either concentration of myclobutanil, although only seven isolates were tested from this vineyard.

\section{Penconazole}

Isolates from most of the Marlborough vineyards showed substantial colony growth on $1 \mathrm{mg} /$ litre penconazole, but there was only one vineyard $\left({ }^{*} \mathrm{M} 2\right)$ with any growth on $10 \mathrm{mg} /$ litre and this was from a single isolate (Figure 2). Isolates from Hawke's Bay vineyards were more sensitive, with less growth on $1 \mathrm{mg} /$ litre, than those from Marlborough vineyards, although vineyard $\mathrm{HB} 10$ had several isolates showing substantial growth on $1 \mathrm{mg} /$ litre. Regional mean colony diameter on $1 \mathrm{mg} /$ litre penconazole was significantly greater (lower sensitivity) for Marlborough than for Hawke's Bay (Table 3). Regional mean diameters were less for penconazole than for myclobutanil, indicating overall greater sensitivity to penconazole than to myclobutanil. 


\section{Cyproconazole}

There were generally smaller colony diameters for cyproconazole than for myclobutanil or penconazole, indicating overall greater sensitivity to cyproconazole (Figure 3). Marlborough vineyards showed greater colony growth on $1 \mathrm{mg}$ /litre than did Hawke's Bay vineyards, indicating lower cyproconazole sensitivity in Marlborough. For Marlborough the mean colony diameter on $1 \mathrm{mg} /$ litre was significantly greater than for Hawke's Bay (Table 3). There was no growth recorded on $10 \mathrm{mg} /$ litre cyproconazole in either region.

\section{Trifloxystrobin}

Substantial colony growth occurred on trifloxystrobin-treated leaves at both $1 \mathrm{mg}$ /litre and $10 \mathrm{mg} /$ litre in both regions (Figure 4), indicating that most of the E. necator isolates were highly resistant to trifloxystrobin. Marlborough isolates showed greater colony growth than Hawke's Bay isolates on $1 \mathrm{mg} /$ litre, but growth of isolates from the different regions was not significantly different on $10 \mathrm{mg} / \mathrm{L}$ (Table 3 ).

\section{Interpreting practical resistance from relative growth}

Mean $\mathrm{EC}_{50}$ values for each fungicide and region were estimated from relative growth at the regional level (Table 4). For myclobutanil at $1 \mathrm{mg} / \mathrm{litre}$, mean relative growth was very high in both regions, especially in Marlborough (Table 4). The estimated $\mathrm{EC}_{50}$ values for both regions indicate overall E. necator populations with low to moderate myclobutanil resistance. Gubler et al. (1996) considered E. necator isolates with $\mathrm{EC}_{50}$ $>0.8 \mathrm{mg} /$ litre to be resistant. The estimated Hawke's Bay $\mathrm{EC}_{50}$ value for myclobutanil of $2.93 \mathrm{mg} /$ litre is consistent with values obtained for four individual Hawke's Bay isolates in two preliminary tests in 2014 (P. Wright, unpublished data). These tests gave mean $\mathrm{EC}_{50}$ values from a dose response curve of 1.5 and $3.8 \mathrm{mg} /$ litre.

For penconazole, the Hawke's Bay E. necator population was generally sensitive $\left(\mathrm{EC}_{50}=0.14\right)$, whereas in Marlborough the estimated $\mathrm{EC}_{50}$ of 1.47 suggested an overall population that had a low level of resistance (Table 4). There was greater sensitivity to cyproconazole than to the other DMIs. In Hawke's Bay, E. necator populations were highly sensitive to cyproconazole, with a mean $\mathrm{EC}_{50}$ of $<0.1 \mathrm{mg} /$ litre. Marlborough populations were also generally sensitive, although less so than Hawke's Bay populations $\left(\mathrm{EC}_{50}=0.31 \mathrm{mg} / \mathrm{litre}\right)$ and there was evidence that cyproconazole sensitivity is decreasing in Marlborough. Three out of the four organic vineyard populations had no resistance to cyproconazole and the fourth, a Marlborough vineyard, showed slight resistance.

Table 4 Regional means for percentage relative growth of Erysiphe necator on myclobutanil (myclo), penconazole (penco), cyproconazole (cypro) and trifloxystrobin (triflo), each at two concentrations. $\mathrm{EC}_{50}$ values were estimated by regression of relative growth values on $\log _{10}$ of concentration.

\begin{tabular}{|c|c|c|c|c|}
\hline & \multirow[b]{2}{*}{ Hawke's Bay (\%) } & \multirow[b]{2}{*}{ Marlborough (\%) } & \multicolumn{2}{|c|}{ Estimated $\mathrm{EC}_{50}(\mathrm{mg} / \mathrm{L})$} \\
\hline & & & Hawke's Bay & Marlborough \\
\hline Myclo $1 \mathrm{mg} /$ litre & 88 & 115 & 2.93 & 5.04 \\
\hline Myclo $10 \mathrm{mg} /$ litre & 7.2 & 23 & & \\
\hline Penco $1 \mathrm{mg} /$ litre & 27 & 60 & 0.14 & 1.47 \\
\hline Penco 10 mg/litre & 0.00 & 0.79 & & \\
\hline Cypro $1 \mathrm{mg} /$ litre & 10 & 33 & $<0.1$ & 0.31 \\
\hline Cypro $10 \mathrm{mg} /$ litre & 0.00 & 0.00 & & \\
\hline Triflo $1 \mathrm{mg} /$ litre & 69 & 115 & $>100$ & $>100$ \\
\hline Triflo $10 \mathrm{mg}$ /litre & 77.90 & 85.07 & & \\
\hline
\end{tabular}




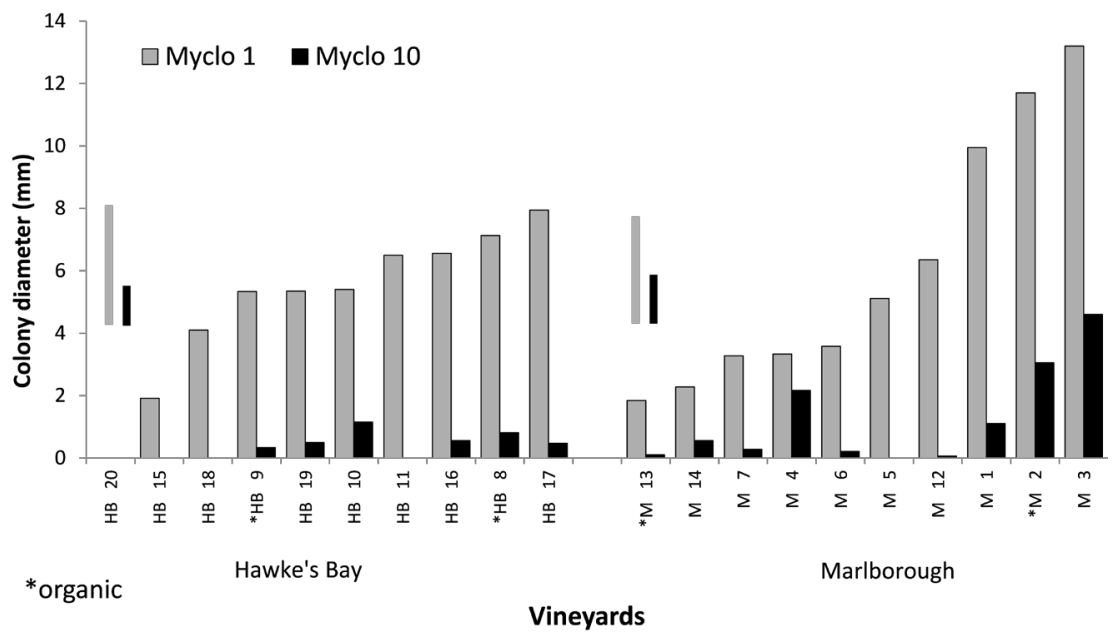

Figure 1 Effect of myclobutanil (Myclo) at 1 and $10 \mathrm{mg} /$ litre on growth of Erysiphe necator isolates from 10 vineyards in Hawke's Bay and 10 in Marlborough, using a detached leaf fungicide sensitivity assay. Vineyards within each region are ranked by mean colony diameter at $1 \mathrm{mg} / \mathrm{litre}$. Vertical lines indicate the least significant difference between vineyard means within a region (Fisher's Protected LSD, $\alpha=0.05$ ).

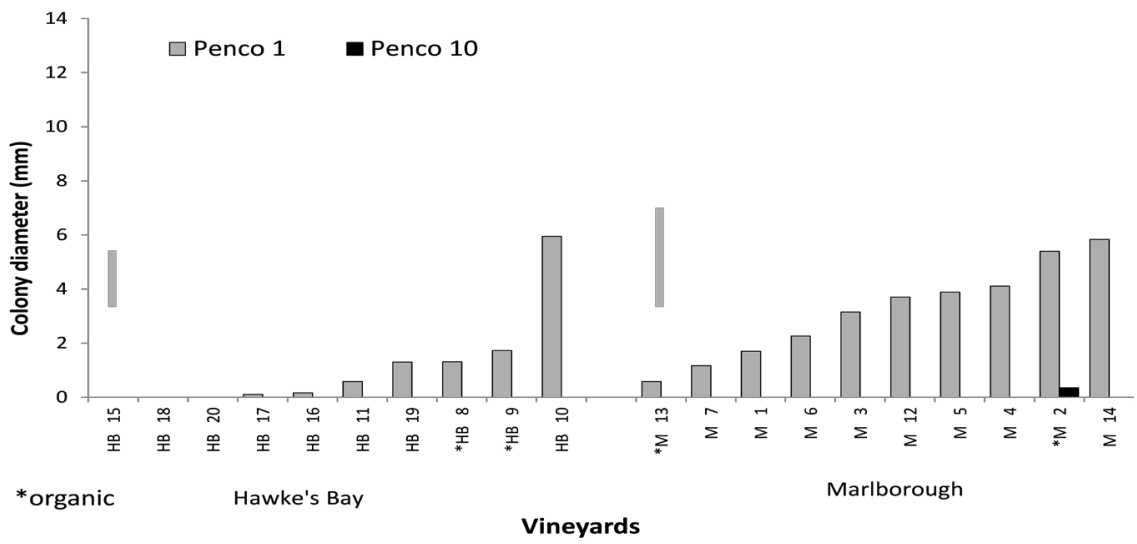

Figure 2 Effect of penconazole (Penco) at $1 \mathrm{mg} /$ litre and $10 \mathrm{mg} /$ litre on growth of Erysiphe necator isolates from 10 vineyards in Hawke's Bay and 10 in Marlborough, using a detached leaf fungicide sensitivity assay. Vineyards within each region are ranked by mean colony diameter at $1 \mathrm{mg} / \mathrm{litre}$. Vertical lines indicate the least significant difference between vineyard means within a region (Fisher's Protected LSD, $\alpha=0.05$ ). 


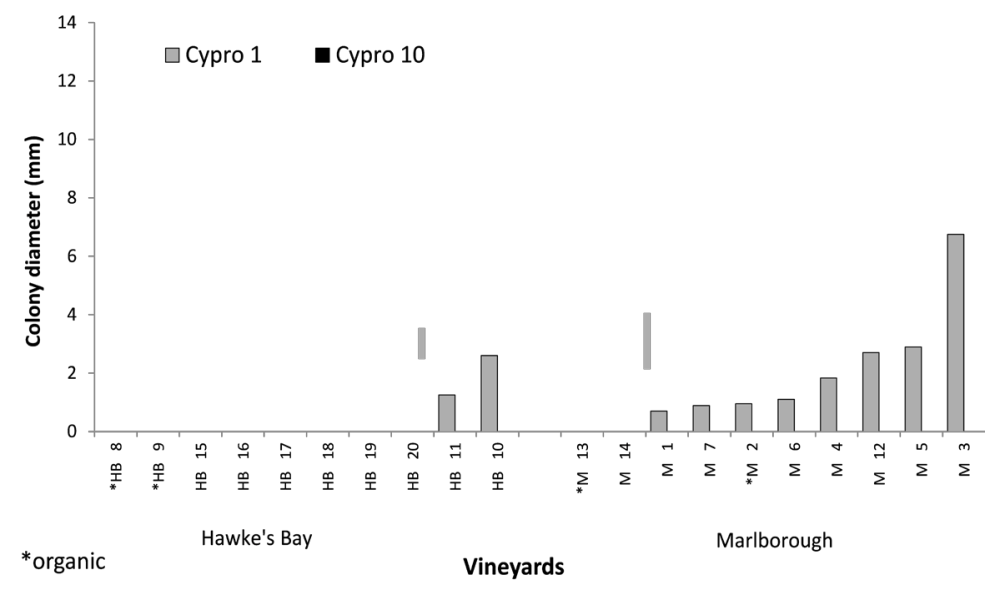

Figure 3 Effect of cyproconazole (Cypro) at $1 \mathrm{mg} /$ litre and $10 \mathrm{mg} /$ litre on growth of Erysiphe necator isolates from 10 vineyards in Hawke's Bay and 10 in Marlborough, using a detached leaf fungicide sensitivity assay. Vineyards within each region are ranked by mean colony diameter at $1 \mathrm{mg} /$ litre. Vertical lines indicate the least significant difference between vineyard means within a region (Fisher's Protected LSD, $\alpha=0.05$ ).

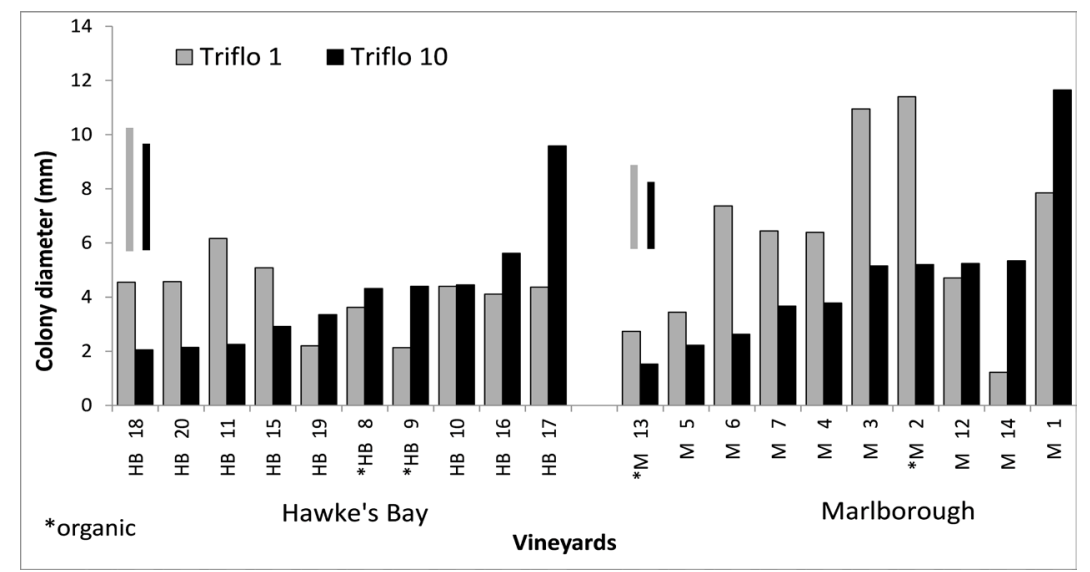

Figure 4 Effect of trifloxystrobin (Triflo) at $1 \mathrm{mg} /$ litre and $10 \mathrm{mg} /$ litre on growth of Erysiphe necator isolates from 10 vineyards in Hawke's Bay and 10 in Marlborough, using a detached leaf fungicide sensitivity assay. Vineyards within each region are ranked by mean colony diameter at $10 \mathrm{mg} /$ litre. Vertical lines indicate the least significant difference between vineyard means within a region (Fisher's Protected LSD, $\alpha=0.05$ ). 
Table 5. Total number of demethylation inhibitor (DMI) and Quinone outside Inhibitor (QoI) fungicide applications over 10 seasons from 2005/2006 to 2014/2015 in 10 Hawke's Bay and 10 Marlborough vineyards sampled for Erysiphe necator resistance in 2015. There was no use of DMI and QoI active ingredients other than the four listed, and the only QoI product used was a mixture of pyraclostrobin (QoI) and boscalid (succinate dehydrogenase inhibitor). The regional totals include fungicides used in two organic vineyards in each region prior to organic registration.

\begin{tabular}{lccccc}
\hline & \multicolumn{3}{c}{ DMI } & & QoI \\
\cline { 2 - 4 } \cline { 5 - 6 } & Myclobutanil & Penconazole & Cyproconazole & & $\begin{array}{c}\text { Pyraclostrobin }+ \\
\text { boscalid }\end{array}$ \\
\hline Hawke's Bay & 69 & 13 & 0 & 0 \\
Marlborough & 73 & 48 & 2 & 4 \\
\hline
\end{tabular}

The cyproconazole $\mathrm{EC}_{50}$ estimate in Hawke's Bay seems a little low. However, it is clear that Hawke's Bay E. necator populations were more sensitive to cyproconazole than the Marlborough populations. Trifloxystrobin showed poor inhibition of colony growth even at $10 \mathrm{mg} /$ litre in every vineyard, including the organic vineyards. The results of this study were consistent with a preliminary QoI fungicide test done in 2014 in which four Hawke's Bay E. necator isolates were tested using azoxystrobin at $0,1,3,10,30$ and $100 \mathrm{mg} /$ litre (P. Wright, unpublished data). No inhibition of colony growth was detected in that test, even at $100 \mathrm{mg} / \mathrm{L}$.

\section{Sensitivity in relation to fungicide use history}

Fungicide use data were summarised for 10 seasons, from 2005/2006 to 2014/2015 (Table 5). For years prior to 2005, the questionnaire returns provided inconsistent information, so no summary could be made. Seasons with missing information for a given fungicide were interpreted as zero, thus the data in Table 5 may underestimate total use of these fungicides, particularly myclobutanil, which was the most used of the fungicides, by about $15 \%$. There was a surprisingly small amount of QoI use reported for the high degree of QoI resistance that was found, particularly for Hawke's Bay, where there was no reported QoI use. QoIs have been registered for use in wine grapes since about 2000. For DMIs, there was no reported use of triforine (currently registered) or fenarimol (registered up to 2010). The fungicide use data provided little explanation

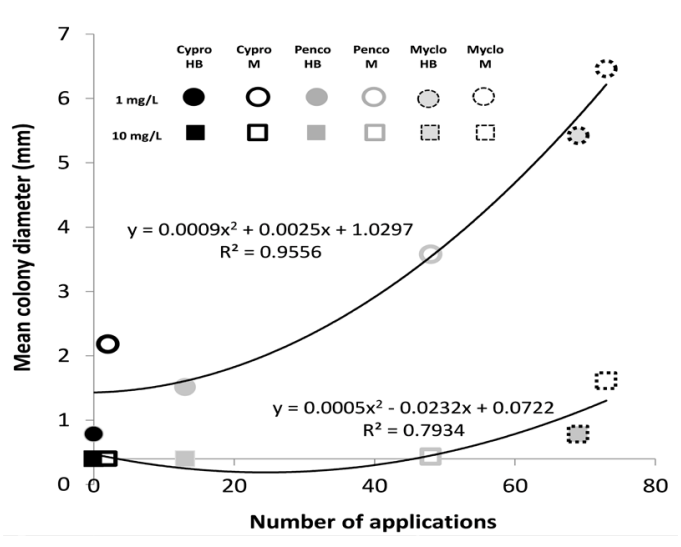

Figure 5 Association between the number of demethylation inhibitor (DMI) fungicide applications per region over 10 growing seasons (2005/2006 to 2014/2015) for each of three DMIs (myclobutanil, penconazole and cyproconazole) and the mean colony diameter of Erysiphe necator on detached grape leaves in the presence of each fungicide at two concentrations $(1 \mathrm{mg} /$ litre and $10 \mathrm{mg} /$ litre). Data are summarised at the regional level for 159 E. necator isolates from 10 Hawke's Bay (HB) vineyards and 187 isolates from 10 Marlborough (M) vineyards.

of the different degrees of resistance in E. necator in individual vineyards. However, for DMIs at the regional level, use reflected the trends in DMI resistance in the detached leaf assay (Figure 5). For the $1 \mathrm{mg} / \mathrm{L}$ concentration there was a strong tendency, across both regions and all DMI active 
ingredients, for the degree of resistance (colony diameter) to increase with the number of DMIs applied historically, suggesting that greater use of any DMI contributed to greater resistance, irrespective of the active ingredient. This trend was clearer at the rate of $1 \mathrm{mg} /$ litre than at $10 \mathrm{mg} /$ litre, where colony diameter was inhibited to a much greater degree, but was evident for myclobutanil at $10 \mathrm{mg} / \mathrm{L}$.

\section{DISCUSSION}

This study suggests that vineyard populations of E. necator in Hawke's Bay and Marlborough are almost completely resistant to trifloxystrobin. It is probable that the $\mathrm{G} 143 \mathrm{~A}$ mutation in the cytochrome $\mathrm{b}$ gene, which is known to confer resistance in E. necator to all QoI fungicides (Dufour et al. 2011), is widely established in New Zealand vineyards. Testing by BASF in Germany of New Zealand E. necator isolates collected from two Hawke's Bay vineyards in May 2015 showed that the G143A mutation was present in all 12 isolates tested (Appendix). Nine of these isolates showed a resistance frequency $>50 \%$, indicating a high degree of QoI resistance. Based on this assumption, vineyard managers would be unwise to rely on QoI fungicides in the future for powdery mildew control in New Zealand vineyards.

Myclobutanil resistance was found in both regions, but particularly in Marlborough, where the climate is drier and where powdery mildew tends to be more problematic. Although loss of disease control may not be obvious in vineyards with a low degree of resistance, if myclobutanil were used in some of the more myclobutanil-resistant vineyards in Hawke's Bay and Marlborough, only partial control of E. necator would be expected. There was some loss of sensitivity to penconazole, again particularly in Marlborough. E. necator showed greater sensitivity to cyproconazole than to the other two DMIs. However, the trend for lower cyproconazole sensitivity in Marlborough than in Hawke's Bay may be similar to the situation with the other two DMIs, where ongoing
DMI use results in a gradual loss of sensitivity.

Cross-resistance of individual E. necator isolates to the different DMI active ingredients could not be determined in this study because inconsistent infection of the detached grape leaves meant many isolates did not grow on all three DMIs. The high degree of growth inhibition by penconazole and cyproconazole, compared with myclobutanil, appears to suggest a lack of DMI cross-resistance. However, the strong relationship at the regional level between resistance (indicated by mean colony diameter at $1 \mathrm{mg} /$ litre) and the number of applications of any DMI active ingredient suggests that the degree of resistance is related to overall DMI use. On this basis, greater reliance in the future on penconazole and cyproconazole could result in the selection of greater resistance to these fungicides.

The findings from this study have been used by the New Zealand Committee on Pesticide Resistance and New Zealand Winegrowers to revise the fungicide resistance management strategy for grape vine powdery mildew in New Zealand (Beresford et al. 2015).

\section{ACKNOWLEDGEMENTS}

We thank BASF New Zealand Limited, Adria Crop Protection Limited, Etec Crop Solutions, Syngenta Crop Protection and Bayer Cropscience for contributing funding for this research.

\section{REFERENCES}

Baudoin A, Olaya G, Delmotte F, Colcol JF, Sierotzki H 2008. QoI resistance of Plasmopara viticola and Erysiphe necator in the Mid-Atlantic United States. Plant Health Progress doi:10.1094/PHP-2008-0211-02-RS. Beresford RM, Follas GB, Hagerty GC, Manson P, Manktelow DWL, Lupton T 2015. Fungicide Resistance Management Strategy for Grapevine Powdery Mildew (Erysiphe necator) in New Zealand. New Zealand Plant Protection Society, issued 10 August 2015. http://resistance.nzpps.org/index. php? $\mathrm{p}=$ crops/grapes_powderymildew. Downloaded 23 March 2016.

Brent KJ 1995. Fungicide resistance in crop 
pathogens: How can it be managed? FRAC monograph No. 1. GIFAP, Brussels, Belgium. $48 \mathrm{p}$.

Delye C, Laigret F, Corio-Costet M-F 1997. A mutation in the 14a-demethylase gene of Uncinula necator that correlates with resistance to a sterol biosynthesis inhibitor. Applied and Environmental Microbiology 63: 2966-2070.

Dufour M-C, Fontaine S, Montarry J, CorioCostet M-F 2011. Assessment of fungicide resistance and pathogen diversity in Erysiphe necator using quantitative real-time PCR assays. Pest Management Science 67(1): 6069.

Gubler W, Ypema H, Ouimette D, Bettiga L 1996. Occurrence of resistance in Uncinula necator to triadimefon, myclobutanil, and fenarimol in California grapevines. Plant Disease 80: 902-909.
Halleen F, Holz G, Pringle KL 2000. Resistance in Uncinula necator to triazole fungicides in South African Grapevines. South African Journal of Enology and Viticulture 21: 71-80. Miles LA, Miles TD, Kirk WW, Schilder AMC 2012. Strobilurin (QoI) resistance in populations of Erysiphe necator on grapes in Michigan. Plant Disease 96:1621-1628.

Savocchia S, Stummer BE, Wicks TJ, van Heeswijck, R, Scott E 2004. Reduced sensitivity to sterole dementhylation inhibiting fungicide in southern Australian vineyards. Australasian Plant Pathology 33: 465-473.

Shabi E, Gaunt RE 1992. Measurement of sensitivity to DMI fungicides in populations of Uncinula necator. New Zealand Plant Protection 45: 126-128.

\section{APPENDIX}

Results of testing for the G143A mutation of the cytochrome b gene that confers resistance in Erysiphe necator to Quinone outside Inhibitor (QoI) fungicides carried out by BASF in Germany. Twelve New Zealand E. necator isolates were collected from two Hawke's Bay vineyards in May 2015. Two blocks were sampled in one vineyard (samples 35 to 43) and one block was sampled in the second vineyard (samples 44 to 46). Reproduced with permission of Grant Hagerty, BASF New Zealand.

\begin{tabular}{|c|c|c|c|c|c|c|} 
& Sample ID & Arrival date & $\begin{array}{c}\text { Sampling } \\
\text { date }\end{array}$ & Country & $\begin{array}{c}\text { Collector resistance } \\
\text { (G143A) }\end{array}$ \\
\hline Qol sensitiv (G143) strain & 1030 & $13-10-11$ & & FR & 0 \\
\hline Qol resistant (A143) strain & 1012 & $10-05-11$ & & & $\mathbf{1 0 0}$ \\
\hline Block 1 Leaf 1 & 35 & $22-06-15$ & $12-05-15$ & NZ & Grant C Hagerty & $\mathbf{7 5}$ \\
\hline Block 1 Leaf 2 & 36 & $22-06-15$ & $12-05-15$ & NZ & Grant C Hagerty & $\mathbf{7 9}$ \\
\hline Block 1 Leaf 3 & 37 & $22-06-15$ & $12-05-15$ & NZ & Grant C Hagerty & 94 \\
\hline Block 1 Leaf 4 & 38 & $22-06-15$ & $12-05-15$ & NZ & Grant C Hagerty & $\mathbf{8 9}$ \\
\hline Block 2 Leaf 1 & 39 & $22-06-15$ & $12-05-15$ & NZ & Grant C Hagerty & $\mathbf{1 0 0}$ \\
\hline Block 2 Leaf 2 & 40 & $22-06-15$ & $12-05-15$ & NZ & Grant C Hagerty & $\mathbf{8 9}$ \\
\hline Block 2 Leaf 3 & 41 & $22-06-15$ & $12-05-15$ & NZ & Grant C Hagerty & $\mathbf{9 7}$ \\
\hline Block 2 Leaf 4 & 42 & $22-06-15$ & $12-05-15$ & NZ & Grant C Hagerty & $\mathbf{1 0 0}$ \\
\hline Block 2 Leaf 5 & 43 & $22-06-15$ & $12-05-15$ & NZ & Grant C Hagerty & $\mathbf{1 0 0}$ \\
\hline Block 1 Leaf 1 & 44 & $22-06-15$ & $12-05-15$ & NZ & Grant C Hagerty & $\mathbf{7 2}$ \\
\hline Block 1 Leaf 2 & 45 & $22-06-15$ & $12-05-15$ & NZ & Grant C Hagerty & $\mathbf{4 9}$ \\
\hline Block 1 Leaf 3 & 46 & $22-06-15$ & $12-05-15$ & NZ & Grant C Hagerty & $\mathbf{2 8}$ \\
\hline
\end{tabular}

